\title{
The Effect of Pricing on Demand and Revenue in Federal Reserve ACH Payment Processing
}

\author{
Joanna Stavins and Paul W. Bauer *
}

October 10, 1997

\footnotetext{
* Economist, Federal Reserve Bank of Boston, and Economist, Federal Reserve Bank of Cleveland, respectively. The views expressed in this paper are those of the authors and do not necessarily reflect the views of the Federal Reserve System. We thank Ed Stevens and conference participants at the University of Miami and the Federal Reserve Bank of Cleveland for helpful comments. Christine Gagliardi and Ramy Tadros provided excellent research assistance. Address inquiries to Joanna Stavins, (617) 973-4217, joanna.stavins@bos.frb.org or Paul W. Bauer, (216) 579-3021, paul.w.bauer@clev.frb.org.
} 


\begin{abstract}
Because the automated clearinghouse $(\mathrm{ACH})$ has been found to have lower social costs than paper checks, the Federal Reserve has been promoting more widespread use of ACH by lowering $\mathrm{ACH}$ processing fees. In this paper we have obtained the first numerical estimates of $\mathrm{ACH}$ demand elasticities, a measure of the responsiveness of $\mathrm{ACH}$ demand to price changes. In order to determine how robust the estimates are, various methods were employed to estimate the demand elasticities.

Our results show that the volume of ACH items processed by the Federal Reserve does respond to changes in per-item fees. We find that demand for $\mathrm{ACH}$ credit is elastic, while demand for $\mathrm{ACH}$ debit is inelastic. The difference most likely arises from high customer resistance to automatic payment deduction and from low market penetration of that service among companies. Demand for origination was found to be somewhat more elastic than demand for receipt. We then examined how volume growth initiated by a price cut affected unit costs. Given the relatively large scale economies found for $\mathrm{ACH}$, volume growth leads to lower unit costs. However, to outweigh revenue lost as a result of a price decline, $\mathrm{ACH}$ volume would have to increase by an amount greater than our estimates indicate is likely. Consequently, a decline in per-item ACH fees would likely lead to lower net revenues.
\end{abstract}




\title{
The Effect of Pricing on Demand and Revenue in Federal Reserve ACH Payment Processing
}

\author{
Joanna Stavins and Paul W. Bauer
}

The automated clearinghouse $(\mathrm{ACH})$ is an electronic payments system typically used for small recurring payments between consumers and businesses. In the absence of ACH, most of these payments would be handled with paper checks. Currently about 75 percent of ACH transactions are processed by the Federal Reserve System. The Federal Reserve processes ACH payments for financial institutions, which in turn sell their $\mathrm{ACH}$ services to businesses and individuals (see Section I for more details).

As the unit cost of an $\mathrm{ACH}$ transaction has been found to be significantly below that of a check, ${ }^{1}$ it is somewhat surprising that the volume of ACH transactions constitutes only about 5 percent of the volume of checks. ${ }^{2}$ Little is known about consumer valuation of paper checks versus $\mathrm{ACH}$, but there are several reasons why $\mathrm{ACH}$ has been slow to replace checks. Some people prefer to write checks, some corporations prefer to avoid incurring the fixed set-up costs required to send and receive $\mathrm{ACH}$ payments, and, in some cases, the price of individual $\mathrm{ACH}$ transactions may be higher than the alternatives. While ACH is well suited for many types of recurring payments, it is not convenient for other types of transactions. For example, set-up costs may make $\mathrm{ACH}$ payments uneconomic for nonrecurring payments. Consequently, the market

\footnotetext{
${ }^{1}$ According to Humphrey and Berger (1990) and Wells (1996), the average social cost of processing an ACH item is only about one-third to one-half as much as for a check.

${ }^{2}$ Approximately 65 billion checks were collected in the United States in 1996, compared to about 3 billion ACH transactions. 
potential for $\mathrm{ACH}$ is somewhat limited. But even among its likely uses, the market penetration for $\mathrm{ACH}$ has been low.

A goal of the Federal Reserve is to make the nation's payments system more efficient. One way to accomplish this goal is to promote the use of $\mathrm{ACH}$ in order to increase net social benefits. Because no studies have compared the social benefits of paper checks and ACH, we can only discuss the social costs and not the net benefits. The cost characteristics of ACH processing have been examined repeatedly (see Humphrey [1981, 1982, 1984, 1985], Bauer and Hancock [1995a, 1995b], and Bauer and Ferrier [1996]), ${ }^{3}$ but no studies have examined the effect of changing processing fees on the demand for Federal Reserve $\mathrm{ACH}$ processing.

Given that the Federal Reserve is trying to raise the volume of $\mathrm{ACH}$, it is important to know what effect lowering $\mathrm{ACH}$ fees has on volume and, indirectly, on unit costs. In other words, we need to estimate the price elasticity of demand for $\mathrm{ACH}$, the percentage change in quantity demanded associated with a 1 percent change in price. ${ }^{4}$ Estimates of demand elasticities allow us to predict how much lowering the fees would increase demand. Such estimates can also be combined with an estimate of cost elasticity to predict the effect of lower fees on net revenue from $\mathrm{ACH}$.

After describing the ACH service in section I, we discuss the various models that we estimate to obtain demand elasticities (section II) and the data available for estimating them

\footnotetext{
${ }^{3}$ Bauer and Hancock (1995a) found the marginal cost of ACH to be below the current per-item fees. Thus, the fees could be lowered and still remain above the marginal cost.

${ }^{4}$ The price elasticity of demand (often called demand elasticity) at price $\mathrm{P}$ and quantity $\mathrm{Y}$ is the percentage change in $\mathrm{Y}$ divided by the percentage change in $\mathrm{P}$, or $(\Delta \mathrm{Y} / \mathrm{Y}) \div(\Delta \mathrm{P} / \mathrm{P})=(\mathrm{P} / \mathrm{Y})(\Delta \mathrm{Y} / \Delta \mathrm{P})$. More precisely, the price elasticity $\varepsilon_{\mathrm{yp}}$ is defined as $(\mathrm{P} / \mathrm{Y})(\partial \mathrm{Y} / \partial \mathrm{P})$. If demand is elastic $\left(\varepsilon_{\mathrm{yp}}<-1\right)$, then a quantity increase will be greater than a price decrease, but if demand is inelastic $\left(\varepsilon_{\mathrm{yp}}>-1\right)$, then a quantity increase will be smaller than a price decrease in percentage terms.
} 
(section III). Multiple models are estimated to investigate the robustness of our results. The present analysis uses monthly data on the $\mathrm{ACH}$ per-item prices charged by the Federal Reserve and the $\mathrm{ACH}$ volumes processed by the 12 regional Federal Reserve Banks from 1984 to 1996 to estimate the price elasticities. After presenting our results (section IV), we consider the implications of our demand elasticity estimates for unit cost and net revenue from the $\mathrm{ACH}$ service (section V) and we present some conclusions (section VI).

\section{Automated Clearinghouse Services}

The ACH system is an electronic funds transfer system which can be used to make either credit transfers or debit transfers. With credit transfers (for example, direct payroll deposits), the payor's bank typically initiates the transfer and funds flow from the payor's bank to the payee's bank. With debit transfers (such as mortgage or utility payments), the payee's bank initiates the transfer and receives funds from the payor's bank. The "originator" is the party that initiates the transaction, which could be either a debit or a credit. The party at the other end is called the "receiver." We expect the demand of originators to be more elastic than the demand of receivers because the former presumably choose how the payment is being made.

The split between originators and receivers also gives us our only glimpse into how demand elasticities vary by the size of institutions. ACH originations tend to be predominantly generated by a few large institutions within each Federal Reserve district, whereas receipts are sown much more broadly. For example, based on the monthly data collected between January and June of 1996, the top originator provided 8 percent of the total commercial ACH origination volume and the top 100 originators provided 77.5 percent. By comparison, the top receiver 
represented only 1.5 percent of total commercial receipts and the top 100 receivers represented only 26.6 percent. Differences in demand elasticities among the various customer groups could be helpful in designing a more efficient $\mathrm{ACH}$ pricing system by applying the inverse elasticity (Ramsey pricing) rule. ${ }^{5}$

The five principal participants in $\mathrm{ACH}$ transactions are the payor, the payee, the payor's bank, the payee's bank, and the provider of the ACH service. The Federal Reserve handled about 75 percent of the roughly 3.3 billion commercial ACH transactions processed in $1996 .{ }^{6}$ The remaining share of the market is handled by private sector ACH providers: Visa, New York Automated Clearing House, and American Clearing House (formerly Arizona Clearing House). The per-item fees for Federal Reserve ACH processing, set by the Retail Payments Product Office, have declined significantly over time. Until 1996, the Federal Reserve ACH processing fees were set once a year and remained fixed throughout each year. The 1996 fees were also set in advance, but for the first time they were lowered during the year. ${ }^{7}$

$\mathrm{ACH}$ transactions offer several key advantages over paper instruments. First, in most cases, payors know exactly when the funds will be removed from their accounts, and payees know exactly when the funds will be deposited to theirs. Second, ACH transactions may be more convenient, particularly for recurring payments, because the payor need not remember to write and deliver a paper check, and the payee need not cash or deposit it. Third, the total costs to all parties are lower for ACH transactions than for paper checks (Humphrey and Berger [1990];

\footnotetext{
${ }^{5}$ The concept was developed in Ramsey (1927).

${ }^{6}$ NACHA and Federal Reserve estimates. Government transactions constituted another 600 million.

${ }^{7}$ The second drop in ACH fees occurred in September of 1996, after the end of our sample.
} 
Wells [1996]). Finally, accounting efficiencies may exist for business payors and payees that have implemented financial electronic data interchange to facilitate communications with trading partners. ${ }^{8}$ Given these clear benefits, the Federal Reserve wants to promote as widespread use of $\mathrm{ACH}$ as feasible. Marketing efforts have been successful in at least some instances. For example, a six-week marketing campaign to increase direct deposits among New York teachers raised the use of $\mathrm{ACH}$ by that market segment from 0 to 40 percent. In this paper, by estimating $\mathrm{ACH}$ demand elasticities, we determine whether pricing may also effective in achieving that goal.

\section{Models}

The Federal Reserve sells its ACH processing services to financial institutions, which in turn process payments on behalf of their customers (corporations and individuals). The "downstream" demand for $\mathrm{ACH}$ processing depends, therefore, on the demand by end-users as well as on the "upstream" demand by banks. The demand by end-users is likely to be affected by the price that banks charge for $\mathrm{ACH}$ processing (which in turn is a function of the Federal Reserve's ACH processing fees and other costs), the prices of substitutes (either other ACH processors or other payments methods), and by exogenous factors affecting demand for payments.

Because the Federal Reserve's goal is to increase the efficiency of the payments system, policy makers are concerned with the volume of end-users' demand for ACH, and not with the volume of intermediaries' (that is, depository institutions') demand. However, intermediaries are

${ }^{8}$ See Knudson, Walton, and Young (1994) for a discussion of the potential benefits of financial electronic data interchange (a combination of electronic remittance data and electronic funds transfers) for business payments. 
the Reserve Banks' direct customers, and the available data measure their demand rather than end-users' demand. That does not affect the interpretation of results. As stated by Green (1997), "When intermediaries are unable to exercise monopoly power, their derived demand will faithfully transmit the demand of their customers, the end-users."

The exogenous factors include the level of economic activity and population in the area. For a given price of $\mathrm{ACH}$, areas with higher contemporaneous levels of economic activity are expected to have higher volumes of $\mathrm{ACH}$. We measure those factors with the levels of employment, per capita income, and population in each district. Other district-level factors that may affect volume include local inertia (people may be less willing to switch away from paper in some regions than in others) and local marketing efforts by regional banks. As we cannot measure those effects directly, district dummies are included in the equation as well. ${ }^{9}$

Besides the Federal Reserve's fees, the demand for ACH processing by banks depends on their direct costs of $\mathrm{ACH}$ processing and the costs of substitutes such as check processing. The higher the other costs of $\mathrm{ACH}$ processing, the less responsive demand is likely to be to the Federal Reserve's prices. For example, a large increase in the cost of ACH technology would result in a smaller shift in $\mathrm{ACH}$ demand in response to lower $\mathrm{ACH}$ fees, while an increase in the price of reader-sorters or of the optical character-recognition machines used in paper check processing could increase demand responsiveness for ACH services. However, we have no knowledge of any significant changes in those costs over time. Moreover, even with significant

\footnotetext{
${ }^{9}$ The number of checks written per person has been used as a measure of consumer inertia by some. However, the variable is likely to be correlated with the level of economic activity, having potentially a positive, not a negative, effect on the demand for $\mathrm{ACH}$ payments.
} 
changes in the cost of check processing technology, banks have to maintain their check processing infrastructure.

Prices of other substitutes for Federal Reserve ACH processing may be relevant as well. The lower the prices of substitutes, the lower the demand for the Federal Reserve ACH processing services, everything else constant. The substitutes may include other payments methods as well as private market providers of ACH. Payments now processed with ACH were typically paid by check in the past. While the cost of check processing has not changed significantly over time, the value of float has changed with interest rates. ${ }^{10}$ Float is a transfer from the payee to the payor in a check transaction. The higher the value of float, the more employers lose by switching credit transactions to direct payroll deposit, and the more payees, such as utilities and mortgage companies, gain by switching debit transactions to automatic withdrawal of payments from their payors' (customers') bank accounts. Given that float is directly proportional to the level of interest rates, we include an exogenous measure of interest rates in the estimation. We expect that the higher the interest rates, the lower the demand for $\mathrm{ACH}$ credit and the higher the demand for ACH debit. ${ }^{11}$

The only other relevant substitutes for Federal Reserve ACH processing are either direct exchanges among banks or competition from private market $\mathrm{ACH}$ processors. To determine whether competition from private sector processors affects demand for the Federal Reserve's

\footnotetext{
${ }^{10}$ Float is generated when the payee receives credit before the payor is debited. The value of float per check is typically calculated by multiplying the value of a check by the number of float days per check and the interest rate, and is therefore directly proportional to the interest rate. Check payments typically generate some float, while float for $\mathrm{ACH}$ payments is negligible.

${ }^{11}$ As the check collection process has improved over time, there has been less scope for gains from check float (through remote disbursements, for example). However, float is still considered to be a significant factor in check payments.
} 
$\mathrm{ACH}$ processing, we look at private sector processing more closely. There are three private sector ACH processors: Visa, New York Automated Clearing House, and American Clearing House. The only nationwide private provider of ACH payments processing is Visa, which has competed with the Federal Reserve on a national scale only since 1994. Other private sector providers have focused on their local markets. Even though the fees charged by Visa may be important determinants of current or future demand for Federal Reserve ACH processing, Visa was not a significant market player during the earlier years of the sample for this study. Therefore, data on Visa's fee structure would not be relevant even if they were available. Table 1 shows annual rates of growth in Federal Reserve ACH volume. While volume growth has slowed beginning in the early 1990s, the data do not indicate that Visa's presence in the ACH market affected the Federal Reserve's interregional volume growth.

Also note that demand for the Federal Reserve's ACH services is affected by any increase in the fraction of "on-us" payments (i.e., payments drawn on and deposited at the same bank) due to a higher rate of bank consolidation. Unfortunately, we have no information on the fraction of payments that banks exchange among themselves directly.

\section{A. $\quad$ Model I}

The following demand equation relates the volume of $\mathrm{ACH}$ items processed in district $\mathrm{i}$ in period $\mathrm{t}\left(\mathrm{y}_{\mathrm{it}}\right)$ to the price of $\mathrm{ACH}$ in period $\mathrm{t}\left(\mathrm{p}_{\mathrm{t}}\right)$, to exogenous measures of economic activity (population $\left[\mathrm{POP}_{\mathrm{it}}\right]$, per capita income $\left[\mathrm{INC}_{\mathrm{it}}\right]$, and employment $\left[\mathrm{EMP}_{\mathrm{it}}\right]$ ) in district $\mathrm{i}$ in period $\mathrm{t}$, and to a measure of interest rates (the rate on a 6-month Treasury bill [TBILL $\left.\mathrm{T}_{\mathrm{t}}\right]$ ). District dummies $\left(\beta_{\mathrm{i}}\right)$ control for district-specific factors that are not captured by the above variables. It is 
common to use the double-log specification to estimate price elasticities of demand, because the price coefficient $\left(\beta_{1}\right)$ can then be directly interpreted as the demand elasticity. The log-log specification also allows for nonlinear effects of the regressors:

$\ln \mathrm{y}_{\mathrm{it}}=\beta_{0}+\beta_{1} \ln \mathrm{p}_{\mathrm{t}}+\beta_{2} \ln \mathrm{POP}_{\mathrm{it}}+\beta_{3} \ln \mathrm{INC}_{\mathrm{it}}+\beta_{4} \ln \mathrm{EMP}_{\mathrm{it}}+\beta_{5} \mathrm{TBILL}_{\mathrm{t}}+\beta_{\mathrm{i}}+\epsilon_{\mathrm{it}}$

As explained above, in the case of $\mathrm{ACH}$ processing, prices are set in advance for the following year and do not change in response to changes in demand throughout our sample period. The price of $\mathrm{ACH}$ is therefore exogenous relative to the volume of $\mathrm{ACH}$ and equation (1) can be estimated using the standard ordinary least-squares regression (OLS). Note that in the case of most goods and services supplied in the private market, this assumption would be false, because prices and volumes are typically determined jointly, and a system of simultaneous equations would need to be estimated.

\section{B. Model II}

Equation (1) assumes that $\mathrm{ACH}$ volume is independent of the past volume (except for any indirect effect of the past volume on prices). This assumption may be too stringent.

To determine whether and how past $\mathrm{ACH}$ volume affects current volume, we consider more closely how Federal Reserve ACH prices are set. The Federal Reserve bases its per item fees partly on the volume predictions provided by individual districts. Several factors influence each district's volume predictions. During 1995 and 1996, each district provided an explanation 
of how its predictions of the following year's ACH volume were derived. ${ }^{12}$ Those explanations suggest that while some districts based their expectations about future volumes on exogenous factors affecting their local economy or on information about upcoming bank mergers, most districts relied on their current year's rate of growth and assumed that their ACH volume would continue growing at the same rate during the following year.

To test whether incorporating past growth rates affects our estimation results, we include a measure of lagged growth in model II. The equation below shows that each district's expected volume in period $t\left(\mathrm{y}_{\mathrm{it}}^{\mathrm{e}}\right)$ is determined as the district's last year's volume $\left(\mathrm{y}_{\mathrm{i}, \mathrm{t}-1}\right)$, increased at a rate of growth $g_{\mathrm{i}}$ :

$\mathrm{y}_{\mathrm{it}}^{\mathrm{e}}=\mathrm{y}_{\mathrm{i}, \mathrm{t}-1} \times \mathrm{g}_{\mathrm{i}}$,

where $\mathrm{g}_{\mathrm{i}}$ is the growth rate of volume in district $\mathrm{i}$ from year $\mathrm{t}-2$ to year $\mathrm{t}-1$,

$$
g_{i}=\frac{y_{i, t-1}}{v}
$$

In other words, we assume that each district expects that its volume will grow between period t-1 and $t$ at the rate at which it grew between $t-2$ and $t-1\left(g_{j}\right)$. The expected volume in period $t$ is therefore determined by the volume in $\mathrm{t}-1$ and by the rate of growth from $\mathrm{t}-2$ to $\mathrm{t}-1$. After setting volume predictions, districts adjust their marketing efforts to try to meet them. As a result, the true volume in period $\mathrm{t}\left(\mathrm{y}_{\mathrm{it}}\right)$ may be a function of $\mathrm{g}_{\mathrm{i}}$, the rate of growth of volume between period $\mathrm{t}-2$ and $\mathrm{t}-1$.

\footnotetext{
${ }^{12}$ There is no indication that prices were based on districts' volume predictions prior to that.
} 
We also include some other variables that Reserve Banks might employ to forecast future volume in our model (measured with population, income, and employment). Additional local information about each district is controlled for with district dummies. Taking the predictions into account, the new model to be estimated is ${ }^{13}$

$$
\begin{aligned}
\ln \mathrm{y}_{\mathrm{it}}= & \gamma_{0}+\gamma_{1} \ln \mathrm{p}_{\mathrm{t}}+\gamma_{2} \ln \mathrm{POP}_{\mathrm{it}}+\gamma_{3} \ln \mathrm{INC}_{\mathrm{it}}+\gamma_{4} \ln \mathrm{EMP}_{\mathrm{it}}+ \\
& +\gamma_{5} \ln \mathrm{TBILL}_{\mathrm{t}}+\gamma_{6} \ln \left(\mathrm{g}_{\mathrm{i}}\right)+\gamma_{\mathrm{i}}+\eta_{\mathrm{it}} .
\end{aligned}
$$

Equation (4) becomes

$$
\begin{aligned}
\ln \mathrm{y}_{\mathrm{it}}= & \gamma_{0}+\gamma_{1} \ln \mathrm{p}_{\mathrm{t}}+\gamma_{2} \ln \mathrm{POP}_{\mathrm{it}}+\gamma_{3} \ln \mathrm{INC}_{\mathrm{it}}+\gamma_{4} \ln \mathrm{EMP}_{\mathrm{it}}+ \\
& +\gamma_{5} \ln \mathrm{TBILL}_{\mathrm{t}}+\gamma_{6}\left(\ln \left(\mathrm{y}_{\mathrm{i}, \mathrm{t}-1}\right)-\ln \left(\mathrm{y}_{\mathrm{i}, \mathrm{t}-2}\right)\right)+\gamma_{\mathrm{i}}+\eta_{\mathrm{it}},
\end{aligned}
$$

because $\ln \left(\mathrm{g}_{\mathrm{i}}\right)=\ln \left(\mathrm{y}_{\mathrm{i}, \mathrm{t}-1}\right)-\ln \left(\mathrm{y}_{\mathrm{i},-\mathrm{t}-2}\right)$. Equation (5) includes lagged dependent variables on the right-hand side. The equation can be estimated using OLS only if there is no serial correlation. To test for serial correlation in the presence of lagged dependent variables, we used the Durbin $\mathrm{h}$ statistic. ${ }^{14}$ Serial correlation was rejected.

\footnotetext{
${ }^{13}$ Although the data are compiled monthly and the subscript $t$ denotes a given month's observation throughout the paper, the volume growth rates are annual and are computed based on the previous two years, since each district estimates its annual growth rates.

${ }^{14}$ Durbin (1970).
} 


\section{C. $\quad$ Model III}

We have explained the restricted sense in which prices and volumes of ACH are not determined simultaneously. However, when $\mathrm{ACH}$ prices are determined, volume expectations are taken into account. Individual Federal Reserve districts may predict their ACH volumes for the following year based on their information about upcoming changes in their region, such as banks merging or switching to private-sector providers. The Retail Product Office takes those volume predictions into account in setting next year's $\mathrm{ACH}$ fees.

We applied a two-stage least squares (2SLS) estimation to test whether the results would vary significantly from the OLS results in model I. In the first stage, the ACH per item fees in period $t\left(\mathrm{p}_{\mathrm{it}}\right)$ were regressed on the unit cost of $\mathrm{ACH}$ processing in district $\mathrm{i}$ in period $\mathrm{t}-1\left(\mathrm{c}_{\mathrm{i}, \mathrm{t}-1}\right)$ and on the expected volume of $\mathrm{ACH}$ in district $\mathrm{i}$ in period $\mathrm{t}\left(\mathrm{y}_{\mathrm{it}}{ }^{\mathrm{e}}\right){ }^{15}$ The first stage of the estimation is therefore as follows:

$\mathrm{p}_{\mathrm{it}}=\alpha_{0}+\alpha_{1} \mathrm{c}_{\mathrm{i}, \mathrm{t}-1}+\alpha_{2} \mathrm{y}_{\mathrm{it}}^{\mathrm{e}}+\mathrm{v}_{\mathrm{it}}$.

From equation (2) it follows that

$\mathrm{p}_{\mathrm{it}}=\alpha_{0}+\alpha_{1} \mathrm{c}_{\mathrm{i}, \mathrm{t}-1}+\alpha_{2} \mathrm{y}_{\mathrm{i}, \mathrm{t}-1} \mathrm{~g}_{\mathrm{i}}+\mathrm{v}_{\mathrm{it}}$

where $\mathrm{g}_{\mathrm{i}}$ is defined as in equation (3). The second stage uses predicted prices from equation (6):

\footnotetext{
${ }^{15}$ Although future prices should reflect estimated unit costs $\left(c_{i t}^{e}\right)$ instead of current unit costs $\left(c_{i t-1}\right)$, current costs are taken into account when prices for ACH are set.
} 
$\ln \mathrm{y}_{\mathrm{it}}=\delta_{0}+\delta_{1} \ln { }_{\mathrm{t}}+\delta_{2} \ln \mathrm{POP}_{\mathrm{it}}+\delta_{3} \ln \mathrm{INC}_{\mathrm{it}}+\delta_{4} \ln \mathrm{EMP}_{\mathrm{it}}+\delta_{5} \ln \mathrm{TBILL}_{\mathrm{t}}+\delta_{\mathrm{i}}+\epsilon_{\mathrm{it}}$.

\section{Data}

The ACH price and volume data for the $1984-96$ period are from one of the Federal Reserve's electronic databases, the CORE (Cost and Revenue) data set. We include commercial volume only. While data on government $\mathrm{ACH}$ volume are also available, other (nonprice) factors, such as the recent mandate to eventually forsake all paper checks, are likely to dominate government demand. As discussed earlier, the Federal Reserve processes ACH payments for financial institutions, which may be acting as originator (the party initiating the transaction) or as receiver (the party that receives the transaction instructions). The transactions themselves can be credit (a request for funds to be transferred from the originator to the receiver) or debit payments (an instruction for funds to be transferred from the receiver to the originator). The CORE data set distinguishes among those four types of transactions. The data also separate intraregional payments (that is, within a Federal Reserve district) and interregional payments (that is, across Federal Reserve districts).

Table 1 shows annual volume growth rates for the various types of interregional $\mathrm{ACH}$ service. Figures 1 and 2 show total interregional monthly ACH volumes for the Federal Reserve System in the 1984-96 period, for origination and receipt, respectively. Figure 3 shows the Federal Reserve per item interregional ACH fees over the same period. Throughout the period, interregional volume increased while prices declined. The econometric analysis used in this study isolates the effect of price decline from other factors affecting volume growth. 
Monthly employment, per capita income, and population data were aggregated from county to district level. The employment data are from the U.S. Bureau of Labor Statistics, the per capita income data are from the U.S. Bureau of Economic Analysis, and the population data are from the U.S. Bureau of the Census.

In addition, conversations with representatives of financial institutions provided information about the nature of the $\mathrm{ACH}$ market, including the types of transactions for which $\mathrm{ACH}$ is currently used, the most likely sources of future volume growth, the way changes in Federal Reserve fees are passed on to their customers, the effects of customer resistance on volume growth, the alternatives to the Federal Reserve's ACH processing that they consider viable, and the sectors that are likely to grow in response to $\mathrm{ACH}$ price changes. We utilized that information in formulating our models and interpreting our results.

\section{Estimation Results}

Equations (1) and (5) were estimated using OLS, and equation (7) was estimated using 2SLS. Separate equations were estimated for each type of ACH processing service for which volume and price data were available:
a. interregional credit origination volume,
b. interregional debit origination volume,
c. total interregional origination volume (a. plus b.),
d. interregional credit receipt volume,
e. interregional debit receipt volume, and
f. total interregional receipt volume (d. plus e.).

Intraregional demand equations could not be estimated, because the intraregional processing fee has been constant since 1985. As no price changes were observed, the data would not allow for 
estimation of what happens when the price rises or falls. Although no data were available by customer size, we expect the demand of originators to be more elastic than that of receivers. Originators tend to be predominantly large institutions, so they are more likely to have some bargaining power with private-sector providers, and originators have more discretion as to how a payment is made.

The results of models I, II, and III are included in Tables 2 through 7. Each table corresponds to a different volume category (a. through f.). Below are the estimates of own-price elasticity of demand for the three models for each volume category. The values are expressed as the percentage change in volume caused by a 1 percent increase in price.

\begin{tabular}{|c|c|c|c|}
\hline ACH Service & \multicolumn{3}{|c|}{ Estimates of Own-Price Elasticity of Demand } \\
\hline (all interregional) & Model I & Model II & Model III \\
\hline Credit Origination & $-1.49 *$ & $-1.44^{*}$ & $-2.34 *$ \\
\hline Debit Origination & -0.36 & 0.24 & $1.10 *$ \\
\hline Total Origination & $-0.97 *$ & $-0.70 *$ & $0.35 *$ \\
\hline Credit Receipt & $-1.02 *$ & $-1.22 *$ & $-1.58 *$ \\
\hline Debit Receipt & $-0.37 *$ & $-0.49 *$ & -0.09 \\
\hline Total Receipt & $-0.63^{*}$ & $-0.85^{*}$ & $-0.50 *$ \\
\hline
\end{tabular}

Estimates marked with an asterisk were significant at the 1 percent level. Most of the results are qualitatively similar across the three models. In particular, results of the estimation with the previous year's rate of volume growth (model II) seem very close to the OLS estimates (model I). 
While most estimates are statistically significant, credit origination and credit receipt are the only volume categories facing elastic demand. In other words, a 1 percent drop in credit origination or credit receipt price leads to an increase of more than 1 percent in volume. At the same time, a 1 percent drop in debit origination or debit receipt price leads to an increase of less than 1 percent in volume. Most of the estimates show that a decrease in $\mathrm{ACH}$ price leads to an increase in all the volumes.

Origination seems to be somewhat more sensitive to price changes than receipt, confirming our prior belief. Originators, which tend to be large, can more easily switch either to direct exchange or to private market processors. Smaller institutions typically have fewer options. However, the biggest difference in demand elasticity estimates is between ACH credit and ACH debit. The difference is likely caused by consumer resistance to debit transactions (such as automated bill payment), or by the relatively few companies offering automatic deduction, or both. Consumer surveys show that a large fraction of the population prefers writing checks to having their payments automatically deducted from their bank accounts. ${ }^{16}$ There is less consumer resistance in the case of credit, such as direct payroll deposit, when payments are deposited into their accounts. As a result, employers are responsive to price incentives from their banks.

On May 1, 1997 the ACH per item origination fee declined from 1 cent to 0.9 cent for low-volume originators and from 1 cent to 0.7 cent for high-volume originators. Given our estimates of demand elasticities, a decline from 1 cent to 0.9 cent (a 10 percent decline) is estimated to lead to a 9.7 percent increase in the interregional origination volume for low-volume

\footnotetext{
${ }^{16}$ NACHA Electronic Check Council (1996).
} 
customers, and a decline from 1 cent to 0.7 cent (a 30 percent decline) would result in a 29.1 percent increase in the interregional origination volume for high-volume users.

To examine regional variation in demand elasticities for $\mathrm{ACH}$, we included interaction terms of the price variable with the district dummies. The results (not reported here) showed that demand elasticities vary across the regions, indicating that not all region-specific effects were picked up by the variables included in the model. The effects of the other variables on the volume of $\mathrm{ACH}$ can be summarized as follows:

Per capita income positive and highly significant, with values slightly higher for origination than for receipt.

Employment positive effect on credit, negative effect on debit; higher employment levels increase demand for direct deposit, raising demand for $\mathrm{ACH}$ credit.

Population negative and significant effect; possibly picks up some of the effect of the other economic indicators.

Interest Rates negative on credit, positive on debit. The overall effect on the origination volume is negative and significant. Higher interest rates lead to higher float, making ACH less attractive to banks and employers.

\section{Implications for Unit Cost}

Previous studies have found significant scale economies in $\mathrm{ACH}$ processing (see Bauer and Ferrier [1996], Bauer and Hancock [1995a], and Humphrey [1982, 1984, 1985]). The estimates of cost elasticities for $\mathrm{ACH}$ have generally ranged from 0.5 to 0.75 . In other words, a 
1 percent increase in $\mathrm{ACH}$ volume leads to only a 0.5 to 0.75 percent increase in the total cost of $\mathrm{ACH}$. Based on those estimates, a 1 percent increase in $\mathrm{ACH}$ volume leads to a 0.5 to 0.25 percent decrease in the unit cost. ${ }^{17}$

Given the scale economies that have been found in Federal Reserve $\mathrm{ACH}$ processing, it is important to consider the effect that price changes may have on production costs. To calculate the effect of a 1 percent decline in price on the unit cost, the effect of a price decline on volume (measured by demand elasticity) can be combined with the effect of an increase in volume on unit cost (measured by cost elasticity):

$$
\frac{\partial \ln \left(\frac{C(y)}{y}\right)}{\partial \ln p}=\left(\frac{\partial \ln C}{\partial \ln y}-1\right) \frac{\partial \ln y}{\partial \ln p},
$$

where the first term on the right-hand side is the cost elasticity minus one and the second term is the price elasticity of demand. As long as the demand elasticity is negative and the cost elasticity is less than one (that is, scale economies exist), the unit cost will decline with a reduction in price. In fact, if the demand elasticity is greater than $1 /(1-\partial \ln C / \partial \ln y)$, the percentage decline in unit cost will be greater than the percentage decline in price, so that the price reduction could be "self-financing" (see the appendix for the derivation of the effect of price reduction on net revenue from $\mathrm{ACH}$ ). Another special case occurs if cost elasticity is equal to 1 (that is, there are constant

\footnotetext{
${ }^{17}$ The effect of a 1 percent increase in volume on the unit cost can be derived from cost elasticity as follows: $\frac{\partial \ln \left(\frac{C}{y}\right)}{\partial \ln y}=\frac{\partial(\ln C-\ln y)}{\partial \ln y}=\frac{\partial \ln C}{\partial \ln y}-1=\varepsilon_{c y}-1$.
} 
returns to scale). In this case, it can be seen from the above equation that changing prices will have no effect on unit costs.

While all of the cost studies mentioned above found evidence for significant scale economies, all of them employed data generated before the full implementation of the Federal Reserve Automation Services (FRAS) consolidation. Some adjustments should therefore be made to obtain the best estimate of the cost elasticity that can be applied in the Federal Reserve System's current circumstances. Beginning with Humphrey (1982), single-equation estimates of $\mathrm{ACH}$ cost elasticities have been around 0.75, even though the volume of $\mathrm{ACH}$ has grown significantly since then. One approach is therefore to assume that the estimates will remain around 0.75. Another approach is to use the most recent estimate (Bauer and Ferrier [1996]) and extrapolate it out to the current consolidated volume levels to estimate the current cost elasticity. ${ }^{18}$ Extrapolating it out to the current system-wide volume level yields a cost elasticity estimate of 0.6. ${ }^{19}$ Given this uncertainty, we employ two separate estimates of the cost elasticities (0.75 and 0.60$)$ to demonstrate the range of likely outcomes.

As can be seen in Tables 8 and 9, the percentage change in unit cost is smaller than the percentage change in prices, other things held constant. This suggests that although lowering the price of $\mathrm{ACH}$ will increase demand, the resulting increase in volume alone will not lower the unit

\footnotetext{
${ }^{18}$ Extrapolation is a bit problematic. Bauer and Ferrier (1996) employed a standard translog and an extended translog (with Fourier terms added). The former can be extrapolated to any volume level but is only guaranteed to be a second-order approximation to the cost function about the sample mean. The latter functional form can reliably fit the cost function over a wider interval, but cannot be extrapolated beyond the observed range of the data. Consequently, the translog was employed in our extrapolation.

${ }^{19}$ These numbers should be used cautiously. Not only are the cost elasticity estimates based on preconsolidation data, they are also based on the PACS database, which measures interregional ACH items twice (since some processing occurred in both districts). This contrasts with the CORE database (used to estimate demand elasticities), which counts each item only once. Depending on the real resource costs of interregional processing prior to consolidation, the bias in the above calculation could go either way.
} 
cost sufficiently to compensate for lost revenues. Of course, an increase in volume is not the only possible source of unit cost decline. Bauer and Ferrier (1996) found that technological change leads to a reduction in unit cost of 11 percent a year. What our results in this paper show is that a price decline in excess of technological progress might hurt cost recovery efforts. A more general formula for the effect of an $\mathrm{ACH}$ price reduction on net revenue is included in the appendix. The result shows that with the cost elasticity equal to 0.75 , the demand elasticity must be greater than 4 in absolute value for net revenue to increase as a result of a price decline. None of our estimates approach that level. For example, the demand elasticity for interregional credit origination estimated in model I equals -1.49 . Assuming that revenue was equal to cost prior to the price decline (i.e., py $=\mathrm{C}$ ), the effect of a 1 percent price decline on net revenue equals

$$
\frac{\partial N R}{\partial p}=\frac{p y}{C}\left(\frac{1}{-1.49}+1\right)-0.75
$$

Assuming that revenue was equal to cost prior to the price decline (i.e., py $=C$ ),

$$
\frac{\partial N R}{\partial p}=-0.42
$$

Thus, even for the most elastic market segment, a price decline will lower net revenue.

\section{Conclusions}

Because $\mathrm{ACH}$ has been found to have lower social costs per item than paper checks (see, for example, Wells [1996] and Humphrey and Berger [1990]), the Federal Reserve has been promoting more widespread use of $\mathrm{ACH}$ through marketing and by lowering $\mathrm{ACH}$ processing fees. In this paper, we have obtained the first numerical estimates of $\mathrm{ACH}$ demand elasticities, a 
measure of the responsiveness of $\mathrm{ACH}$ demand to price changes. In order to determine how robust these estimates are, various methods were employed to estimate these demand elasticities.

Our results show that the volume of ACH items processed by the Federal Reserve does respond to changes in per item fees. This suggests either that over the sample period, banks must have passed the lower fees on to their customers or used the extra receipts to promote the service more aggressively. Our estimated demand elasticities are negative and mostly statistically significant. A potentially important finding is that credit demand is more responsive than debit demand. Specifically, we find that credit demand is elastic, while debit demand is inelastic. This difference most likely arises from high customer resistance to automatic payment deduction and from low market penetration of that service among companies. Demand for origination was found to be somewhat more elastic than demand for receipt.

After showing that volume does indeed respond to lower fees, even though the Federal Reserve does not control the ultimate price paid by customers of the service, we then examined how volume growth initiated by a price cut affected unit costs. Given the relatively large scale economies found for $\mathrm{ACH}$, volume growth leads to lower unit costs. However, to outweigh revenue lost as a result of a price decline, $\mathrm{ACH}$ volume would have to increase by an amount greater than our estimates indicate is likely. Consequently, a decline in per item ACH fees would likely lead to lower net revenues.

Before further price decreases are adopted—beyond those justified by technological change and exogenous volume growth—a clearer understanding of the Federal Reserve System's objectives and constraints is required. If the objective is to raise the Federal Reserve's ACH processing volume, a price decline will clearly help accomplish that goal. But if maintaining 
current net revenues is a constraint, a price decrease, other things being equal, is not likely to be possible. Volume could be boosted, while maintaining cost recovery, by adopting "Ramsey pricing" (see Ramsey [1927]). Given that we find that demand elasticities vary across customer classes, ACH use could be promoted by charging higher fees for customers with less elastic demand and lower fees for customers with more elastic demand. Under such a pricing regime, fees could be set in such a way that volume would increase, yet costs would still be recovered. 


\section{Appendix}

This appendix derives the effect of a reduction in price for $\mathrm{ACH}$ service on net revenue from $\mathrm{ACH}$, and shows the condition that must be met for net revenue to increase as a result of a price decline.

The total cost of $\mathrm{ACH}$ processing is a function of the total volume of $\mathrm{ACH}$ items processed by the Federal Reserve, $\mathrm{C}(\mathrm{y})$. Net revenue from $\mathrm{ACH}$ equals

$$
N R=p y-C(y) .
$$

The effect of price change on net revenue is

$$
\frac{\partial N R}{\partial p}=\left(y+p \frac{\partial y}{\partial p}\right)-\left(\frac{\partial C}{\partial y} \frac{\partial y}{\partial p}\right) .
$$

Net revenue increases if

$$
\frac{\partial N R}{\partial p}>0 \Leftrightarrow y+p \frac{\partial y}{\partial p}>\frac{\partial C}{\partial y} \frac{\partial y}{\partial p}
$$

or

$$
\left(\frac{y}{C}\right)\left(\frac{y}{\frac{\partial y}{\partial p}}+p\right)>\frac{\partial C}{\partial y} \frac{y}{C} .
$$

Expressing the above inequality in terms of elasticities, we obtain

$$
\frac{p y}{C}\left(\frac{1}{\varepsilon_{y p}}+1\right)>\varepsilon_{c y} .
$$


The above inequality shows a relationship between the cost elasticity $\left(\boldsymbol{\varepsilon}_{\mathrm{cy}}\right)$ and the price elasticity of demand $\left(\varepsilon_{\mathrm{yp}}\right)$ that must be met for net revenue to increase as a result of a price decrease. If revenue equals cost ( $\mathrm{py}=\mathrm{C}$ ), the first part of the above expression equals 1 . In that case, the condition becomes

$$
\frac{1}{\boldsymbol{\varepsilon}_{y p}}+1>\boldsymbol{\varepsilon}_{c y} \quad \text { or } \quad \boldsymbol{\varepsilon}_{y p}<\frac{1}{\boldsymbol{\varepsilon}_{c y}-1} .
$$

For a cost elasticity of 0.75 , the demand elasticity has to be less than -4 (or greater than 4 in absolute value) for net revenue to increase as a result of a price decrease. A cost elasticity of 0.6 would require a demand elasticity of -2.5 , still larger than any found in our study. 


\section{References}

Bauer, Paul W. and Gary D. Ferrier. 1996. "Scale Economies, Cost Efficiencies and Technological Change in Federal Reserve Payments Processing." Journal of Money, Credit, and Banking, vol. 28, no. 4 (November, Part 2), 1004-1039.

Bauer, Paul W. and Diana Hancock. 1995a. "Scale Economies and Technological Change in Federal Reserve ACH Payment Processing." Federal Reserve Bank of Cleveland, Economic Review (Quarter 3), 14-29.

. 1995b. "Estimation of the Fedwire Funds Transfer Cost Function." Mimeo.

Durbin, James. 1970. "Testing for Serial Correlation in Least Squares Regression When Some of the Regressors Are Lagged Dependent Variables." Econometrica, vol. 38, no. 3 (May), 410-421.

Green, Edward J. 1997. "The Pricing Guidelines for Federal Reserve Payment Services," presented at the FSRG Workshop on Pricing Issues, Federal Reserve Bank of Cleveland, July 18, 1997.

Humphrey, David B. 1981. "Scale Economies at Automated Clearinghouses." Journal of Bank Research, vol. 12 (Summer), 71-81.

. 1982. "Costs, Scale Economies, Competition, and Product Mix in the U.S.

Payments Mechanism." Staff Studies, Board of Governors of the Federal Reserve System (April).

. 1984. "The U.S. Payments System: Costs, Pricing, Competition and Risk." Monograph Series in Finance and Economics, Board of Governors of the Federal Reserve System.

. 1985. "Resource Use in Federal Reserve Check and ACH Operations after Pricing." Journal of Bank Research, vol. 12 (Spring), 45-53.

Humphrey, David B. and Allen N. Berger. 1990. "Market Failure and Resource Use: Economic Incentives to Use Different Payment Instruments." In David B. Humphrey, ed., The U.S. Payment System: Efficiency, Risk, and the Role of the Federal Reserve, 45-86. Boston, MA: Kluwer Academic Publishers.

Knudson, Scott E., Jack K. Walton, and Florence M. Young. 1994. "Business-to-Business Payments and the Role of Financial Electronic Data Interchange." Federal Reserve Bulletin, vol. 80 (April), 269-78.

NACHA Electronic Check Council. 1996. “The Voice of the Consumer: Findings from Focus Group Research" (March). 
Ramsey, Frank P. 1927. "A Contribution to the Theory of Taxation.” Economic Journal, vol. 37, 47-61.

Wells, Kirstin E. 1996. “Are Checks Overused?” Federal Reserve Bank of Minneapolis, Quarterly Review (Fall), 2-12. 


\begin{tabular}{|c|c|c|c|c|c|c|}
\hline \multicolumn{7}{|c|}{ Table 1: Annual Growth Rates in In } \\
\hline & $\begin{array}{l}\text { Interregional } \\
\text { Credit } \\
\text { Origination }\end{array}$ & $\begin{array}{l}\text { Interregional } \\
\text { Debit } \\
\text { Origination }\end{array}$ & $\begin{array}{l}\text { Total } \\
\text { Interregional } \\
\text { Origination }\end{array}$ & $\begin{array}{l}\text { Interregional } \\
\text { Credit } \\
\text { Receipt }\end{array}$ & $\begin{array}{l}\text { Interregional } \\
\text { Debit } \\
\text { Receipt }\end{array}$ & $\begin{array}{l}\text { Total } \\
\text { Interregional } \\
\text { Receipt }\end{array}$ \\
\hline 1985-1986 & 38.53 & 38.84 & 38.73 & 37.49 & 30.86 & 32.78 \\
\hline 1986-1987 & 37.41 & 35.73 & 36.36 & 41.93 & 32.75 & 35.50 \\
\hline $1987-1988$ & 29.70 & 30.35 & 30.11 & 30.06 & 24.01 & 25.90 \\
\hline 1988-1989 & 28.97 & 20.44 & 23.65 & 29.85 & 24.67 & 26.35 \\
\hline 1989-1990 & 28.57 & 52.88 & 43.33 & 27.84 & 14.58 & 18.99 \\
\hline 1990-1991 & 33.63 & 16.00 & 22.21 & 31.12 & 13.37 & 19.72 \\
\hline 1991-1992 & 28.98 & 16.49 & 21.30 & 30.64 & 17.61 & 22.71 \\
\hline 1992-1993 & 26.59 & 15.22 & 19.88 & 26.40 & 14.77 & 19.62 \\
\hline 1993-1994 & 22.17 & 13.41 & 17.20 & 22.96 & 13.91 & 17.89 \\
\hline 1994-1995 & 23.09 & 16.83 & 19.65 & 22.53 & 16.76 & 19.41 \\
\hline 1995-1996 & 24.57 & 16.51 & 20.24 & 21.03 & 15.72 & 18.22 \\
\hline $\begin{array}{c}\text { Average Annual } \\
\text { Growth Rate }\end{array}$ & 29.29 & 24.80 & 26.61 & 29.26 & 19.91 & 23.37 \\
\hline
\end{tabular}

Source: Authors' Calculations. 


\begin{tabular}{|c|c|c|c|c|c|c|}
\hline \multirow[b]{2}{*}{ Variables } & \multicolumn{2}{|c|}{ Model I } & \multicolumn{2}{|c|}{ Model II } & \multicolumn{2}{|c|}{ Model III } \\
\hline & Coefficient & $\mathrm{t}$-Stat. & Coefficient & $\mathrm{t}$-Stat. & Coefficient & t-Stat. \\
\hline Intercept & 2.14 & 0.55 & 13.30 & 3.03 & -0.26 & -0.06 \\
\hline $\log$ (Growth Rate) & --- & --- & 0.33 & 7.47 & --- & --- \\
\hline $\log$ (Price) & -1.49 & -7.84 & -1.44 & -7.65 & -2.34 & -11.43 \\
\hline $\log$ (Population) & -4.68 & -11.25 & -5.12 & -10.76 & -3.72 & -8.01 \\
\hline $\log$ (Per Capita Income) & 3.49 & 21.84 & 4.12 & 24.03 & 3.99 & 31.08 \\
\hline $\log$ (Employment) & 4.69 & 20.76 & 3.85 & 17.11 & 3.36 & 15.32 \\
\hline $\log (6-$ Month T-Bill Rate) & -0.35 & -10.60 & -0.28 & -9.20 & -0.19 & -6.25 \\
\hline District Dummies? & Yes & & Yes & & Yes & \\
\hline $\mathrm{N}$ & 1582 & & 1330 & & 1330 & \\
\hline $\mathrm{R}^{2}$ & 0.934 & & 0.934 & & 0.935 & \\
\hline F & 1380 & & 1095 & & 1172 & \\
\hline
\end{tabular}

Source: Authors' Calculations. 


\section{Table 3: Interregional Debit Origination Volume}

\begin{tabular}{|c|c|c|c|c|c|c|}
\hline \multirow[b]{2}{*}{ Variables } & \multicolumn{2}{|c|}{ Model I } & \multicolumn{2}{|c|}{ Model II } & \multicolumn{2}{|c|}{ Model III } \\
\hline & Coefficient & t-Stat. & Coefficient & t-Stat. & Coefficient & t-Stat. \\
\hline Intercept & 23.26 & 3.87 & 16.80 & 2.52 & 22.85 & 3.22 \\
\hline $\log$ (Growth Rate) & --- & --- & 0.30 & 7.41 & --- & --- \\
\hline $\log$ (Price) & -0.36 & -1.22 & 0.24 & 0.83 & 1.10 & 3.71 \\
\hline $\log$ (Population) & -1.95 & -3.04 & -0.20 & -0.27 & -0.29 & -0.40 \\
\hline $\log$ (Per Capita Income) & 6.28 & 25.43 & 6.88 & 26.22 & 6.91 & 33.60 \\
\hline $\log$ (Employment) & -0.85 & -2.42 & -2.04 & -5.90 & -2.19 & -6.39 \\
\hline $\log (6-$ Month T-Bill Rate $)$ & 0.01 & 0.13 & 0.11 & 2.36 & 0.08 & 1.73 \\
\hline District Dummies? & Yes & & Yes & & Yes & \\
\hline $\mathrm{N}$ & 1583 & & 1331 & & 1331 & \\
\hline $\mathrm{R}^{2}$ & 0.892 & & 0.895 & & 0.892 & \\
\hline $\mathrm{F}$ & 804 & & 658 & & 676 & \\
\hline
\end{tabular}

Source: Authors' Calculations. 


\begin{tabular}{|c|c|c|c|c|c|c|}
\hline \multicolumn{7}{|c|}{ Table 4: Total Interregional Origination Volume } \\
\hline \multirow[b]{2}{*}{ Variables } & \multicolumn{2}{|c|}{ Model I } & \multicolumn{2}{|c|}{ Model II } & \multicolumn{2}{|c|}{ Model III } \\
\hline & Coefficient & t-Stat. & Coefficient & t-Stat. & Coefficient & t-Stat. \\
\hline Intercept & 3.80 & 1.18 & 4.09 & 1.15 & 4.93 & 1.30 \\
\hline $\log$ (Growth Rate) & --- & --- & 0.24 & 6.12 & --- & --- \\
\hline $\log ($ Price $)$ & -0.97 & -6.14 & -0.70 & -4.51 & 0.35 & 2.12 \\
\hline $\log$ (Population) & -2.50 & -7.24 & -1.61 & -4.14 & -1.16 & -2.98 \\
\hline $\log$ (Per Capita Income) & 4.35 & 32.83 & 4.83 & 33.77 & 5.27 & 47.39 \\
\hline $\log$ (Employment) & 2.14 & 11.43 & 1.10 & 5.96 & 0.84 & 4.59 \\
\hline $\log (6-$ Month T-Bill Rate) & -0.16 & -5.94 & -0.08 & -3.29 & -0.09 & -3.36 \\
\hline District Dummies? & Yes & & Yes & & Yes & \\
\hline $\mathrm{N}$ & 1583 & & 1331 & & 1331 & \\
\hline $\mathrm{R}^{2}$ & 0.955 & & 0.957 & & 0.955 & \\
\hline F & 2069 & & 1712 & & 1736 & \\
\hline
\end{tabular}

Source: Authors' Calculations. 


\begin{tabular}{|c|c|c|c|c|c|c|}
\hline \multicolumn{7}{|c|}{ Table 5: Interregional Credit Receipt Volume } \\
\hline \multirow[b]{2}{*}{ Variables } & \multicolumn{2}{|c|}{ Model I } & \multicolumn{2}{|c|}{ Model II } & \multicolumn{2}{|c|}{ Model III } \\
\hline & Coefficient & $\mathrm{t}-$ Stat. & Coefficient & $\mathrm{t}$-Stat. & Coefficient & $\mathrm{t}$-Stat. \\
\hline Intercept & 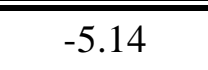 & -2.76 & -11.61 & -5.57 & 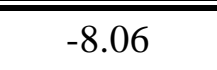 & -3.69 \\
\hline $\log$ (Growth Rate) & --- & --- & -0.47 & -12.02 & --- & --- \\
\hline $\log$ (Price) & -1.02 & -11.19 & -1.22 & -13.42 & -1.58 & -12.26 \\
\hline $\log$ (Population) & 0.22 & 1.13 & 1.21 & 5.34 & 0.73 & 2.97 \\
\hline $\log$ (Per Capita Income) & 4.64 & 60.70 & 3.85 & 40.78 & 4.73 & 75.18 \\
\hline $\log$ (Employment) & 0.002 & 0.02 & -0.25 & -2.28 & -0.53 & -4.84 \\
\hline $\log$ (6-Month T-Bill Rate) & $\begin{array}{l}-0.15 \\
\end{array}$ & -9.26 & -0.17 & -10.93 & $\begin{array}{l}-0.04 \\
\end{array}$ & -2.44 \\
\hline District Dummies? & Yes & & Yes & & Yes & \\
\hline$N$ & 1584 & & 1332 & & 1332 & \\
\hline $\mathrm{R}^{2}$ & 0.982 & & 0.982 & & 0.980 & \\
\hline $\mathrm{F}$ & 5318 & & 4111 & & 4020 & \\
\hline
\end{tabular}

Source: Authors' Calculations. 


\begin{tabular}{|c|c|c|c|c|c|c|}
\hline \multicolumn{7}{|c|}{ Table 6: Interregional Debit Receipt Volume } \\
\hline \multirow[b]{2}{*}{ Variables } & \multicolumn{2}{|c|}{ Model I } & \multicolumn{2}{|c|}{ Model II } & \multicolumn{2}{|c|}{ Model III } \\
\hline & Coefficient & $\mathrm{t}$-Stat. & Coefficient & $\mathrm{t}-$ Stat. & Coefficient & $\mathrm{t}$-Stat. \\
\hline Intercept & 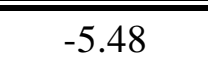 & -2.89 & "-6.01 & -2.85 & 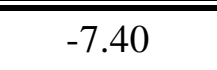 & -3.42 \\
\hline $\log$ (Growth Rate) & --- & --- & -0.37 & -7.66 & --- & --- \\
\hline $\log$ (Price) & -0.37 & -3.95 & -0.49 & -5.37 & -0.09 & -0.70 \\
\hline $\log$ (Population) & 1.03 & 5.07 & 1.56 & 6.79 & 1.84 & 7.90 \\
\hline $\log$ (Per Capita Income) & 3.55 & 45.52 & 2.96 & 31.67 & 3.58 & 56.18 \\
\hline $\log$ (Employment) & -0.22 & -1.99 & -0.62 & -5.64 & $\begin{array}{ll}-0.81 \\
\end{array}$ & -7.37 \\
\hline $\log$ (6-Month T-Bill Rate) & 0.01 & 0.36 & 0.04 & 2.81 & 0.07 & 4.82 \\
\hline District Dummies? & Yes & & Yes & & Yes & \\
\hline$N$ & 1584 & & 1332 & & 1332 & \\
\hline $\mathrm{R}^{2}$ & 0.970 & & 0.971 & & 0.969 & \\
\hline $\mathrm{F}$ & 3178 & & 2584 & & 2589 & \\
\hline
\end{tabular}

Source: Authors' Calculations. 


\section{Table 7: Total Interregional Receipt Volume}

\begin{tabular}{|c|c|c|c|c|c|c|}
\hline \multirow[b]{2}{*}{ Variables } & \multicolumn{2}{|c|}{ Model I } & \multicolumn{2}{|c|}{ Model II } & \multicolumn{2}{|c|}{ Model III } \\
\hline & Coefficient & t-Stat. & Coefficient & t-Stat. & Coefficient & t-Stat. \\
\hline Intercept & -7.69 & -4.13 & -10.02 & -4.88 & -10.61 & -4.87 \\
\hline $\log$ (Growth Rate) & --- & --- & -0.51 & -11.16 & --- & --- \\
\hline $\log$ (Price) & -0.63 & -6.97 & -0.85 & -9.53 & -0.50 & -3.84 \\
\hline $\log$ (Population) & 1.06 & 5.35 & 1.68 & 7.51 & 1.89 & 7.86 \\
\hline $\log$ (Per Capita Income) & 3.86 & 50.52 & 3.08 & 33.04 & 3.97 & 61.98 \\
\hline $\log$ (Employment) & -0.18 & -1.66 & -0.46 & -4.26 & -0.77 & -7.00 \\
\hline $\log (6-$ Month T-Bill Rate $)$ & -0.05 & -3.37 & -0.05 & -3.60 & 0.02 & 1.43 \\
\hline District Dummies? & Yes & & Yes & & Yes & \\
\hline $\mathrm{N}$ & 1585 & & 1332 & & 1332 & \\
\hline $\mathrm{R}^{2}$ & 0.974 & & 0.975 & & 0.971 & \\
\hline $\mathrm{F}$ & 3700 & & 2958 & & 2778 & \\
\hline
\end{tabular}

Source: Authors' Calculations. 


\begin{tabular}{|c|c|c|c|}
\hline \multicolumn{4}{|c|}{$\begin{array}{l}\text { Table 8: Effect of a } 1 \% \text { Decline in Price on Unit Costs } \\
\qquad(\partial \ln C / \partial \ln y=0.75)\end{array}$} \\
\hline ACH Service & Model I & Model II & Model III \\
\hline Credit Origination & $-0.37 *$ & $-0.36^{*}$ & $-0.59 *$ \\
\hline Debit Origination & -0.09 & 0.06 & $0.28 *$ \\
\hline Total Origination & $-0.24 *$ & $-0.18 *$ & $0.09 *$ \\
\hline Credit Receipt & $-0.26^{*}$ & $-0.31 *$ & $-0.40 *$ \\
\hline Debit Receipt & $-0.09 *$ & $-0.12 *$ & -0.02 \\
\hline Total Receipt & $-0.16^{*}$ & $-0.21 *$ & $-0.13 *$ \\
\hline
\end{tabular}

Source: Authors' Calculations. 


\begin{tabular}{|c|c|c|c|}
\hline \multicolumn{4}{|c|}{$\begin{array}{l}\text { Table 9: Effect of a } 1 \% \text { Decline in Price on Unit Costs } \\
\qquad(\partial \ln C / \partial \ln y=0.60)\end{array}$} \\
\hline ACH Service & Model I & Model II & Model III \\
\hline Credit Origination & $-0.60 *$ & $-0.58 *$ & $-0.94 *$ \\
\hline Debit Origination & -0.14 & 0.10 & $0.44^{*}$ \\
\hline Total Origination & $-0.39 *$ & $-0.28 *$ & $0.14 *$ \\
\hline Credit Receipt & $-0.41 *$ & $-0.49 *$ & $-0.63 *$ \\
\hline Debit Receipt & $-0.15^{*}$ & $-0.20 *$ & -0.04 \\
\hline Total Receipt & $-0.25 *$ & $-0.34 *$ & $-0.20 *$ \\
\hline
\end{tabular}

Source: Authors' Calculations. 
Figure 1

\section{Total Interregional Origination Volume}

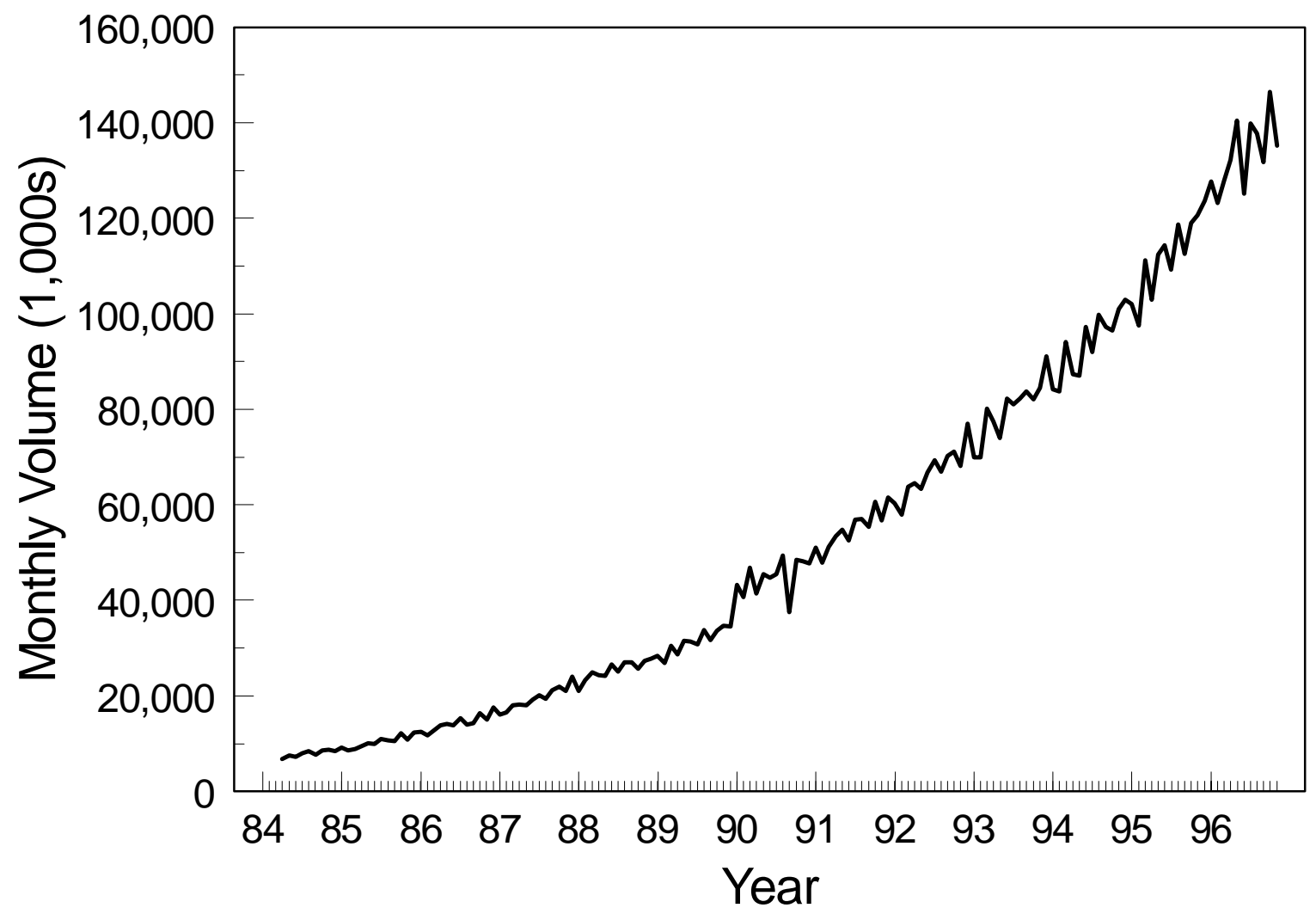

Source: Authors' Calculations. 
Figure 2

\section{Total Interregional Receipt Volume}

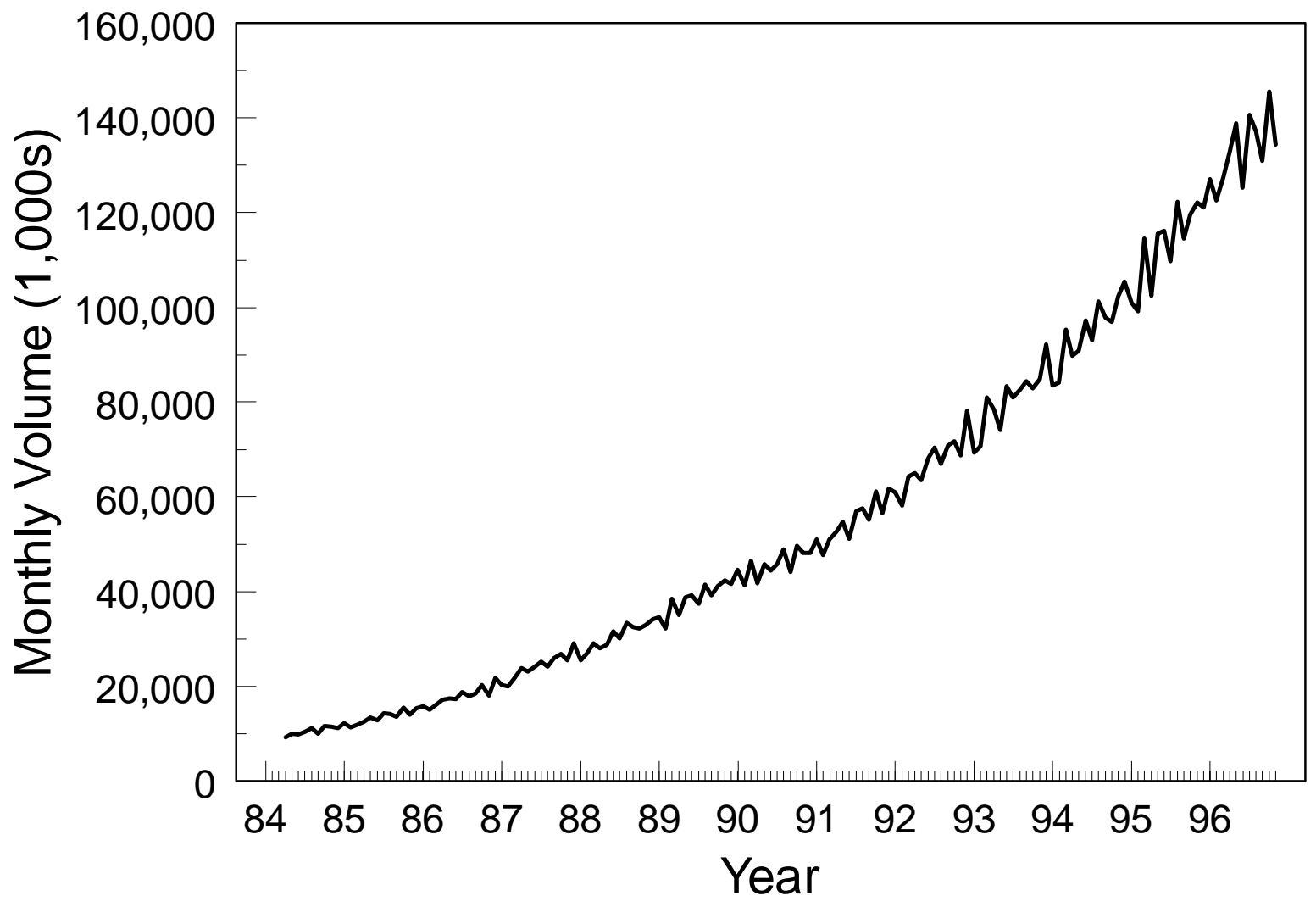

Source: Authors' Calculations. 
Figure 3

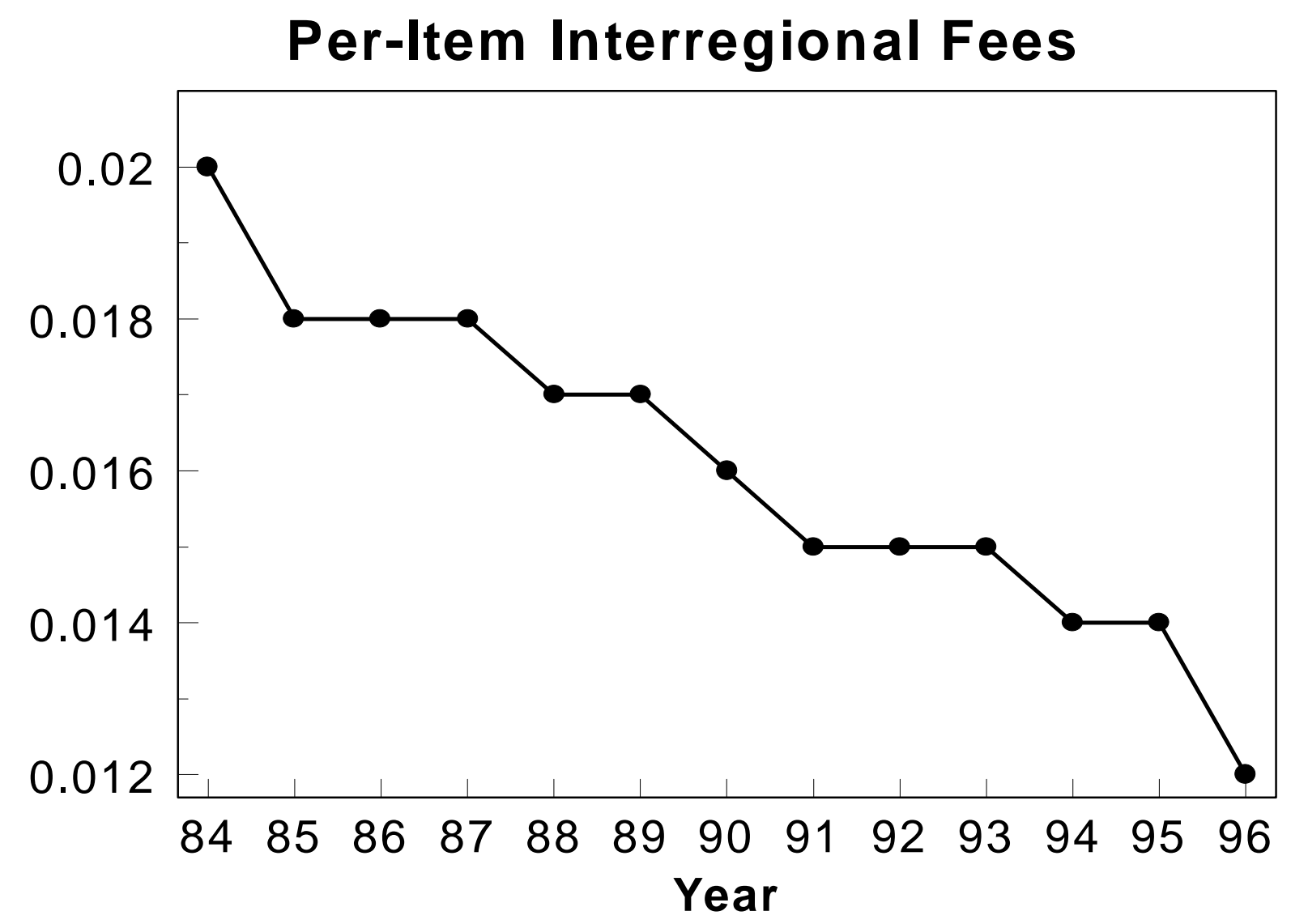

Source: Authors' Calculations. 